\title{
Diversity of Endophytic Fungi Isolated from Gentiana rhodantha and Screening for Biocontrol Stains
}

Zhang Xiaoyong, Li Shujiang, Yan Kai, Xiang Hong, Yang Youlian $\square$

School of Biological Science and Technology, Liupanshui Normal University, Liupanshui, 553004, China

$\downarrow$ Corresponding author email: yangyoulianl@163.com

Molecular Microbiology Research, 2021, Vol.11, No.1 doi: $\underline{10.5376 / \mathrm{mmr} .2021 .11 .0001}$

Received: 13 Aug., 2021

Accepted: 31 Aug., 2021

Published: 10 Sep., 2021

Copyright (c) 2021 Zhang et al., This article was first published in Molecular Plant Breeding in Chinese, and here was authorized to translate and publish the paper in English under the terms of Creative Commons Attribution License, which permits unrestricted use, distribution, and reproduction in any medium, provided the original work is properly cited.

Preferred citation for this article:

Zhang X.Y., Li S.J., Yan K., Xiang H., and Yang Y.L., 2021, Diversity of endophytic fungi isolated from Gentiana rhodantha and screening for biocontrol stains, Molecular Microbiology Research, 11(1): 1-9 (doi: 10.5376/mmr.2021.11.0001)

\begin{abstract}
In order to clarify the composition of endophytic fungi in Gentiana rhodantha in colonization tissues with four Liupanshui sampling sites (Fenghuang Zhongshan, Nankai Shuicheng, Yangmei Shuicheng and Xinchang Liuzhi) in Liupanshui, strains were isolated with health leaf, stem and root and identification based on morphological characteristics and ITS sequence analysis. As well as screening for biocontrol stains by the dural culture method on PDA plates with Sclerotinia sclerotionrum. The results showed that $G$. rhodantha concealed rich fungal diversity, the colonization rate and isolation rate of endophytic fungi reached $49.38 \%$ and $61.25 \%$ respectively. 294 strains of endophytic fungi were obtained from 480 explant tissue segments of G. rhodantha and belonging to 2 phylum, 5 classes, 14 orders and 32 genera; of which Fusarium and Colletotrichum were comparatively advantageous taxa in endophytic fungi of G. rhodantha, and the species contained occupied $9.86 \%$ and $8.84 \%$ of the total endophytes respectively. According to the calculation results, Xinchang LZ in four sites and stem in three tissues showed optimum degrees of diversity, evenness and dominance respectively. 23 strains of endophytic fungi with inhibitory activities against $S$. sclerotionrum by the dural culture method; Amomg them, the inhibition rate of Botryosphaeria sp. R022, R021, Phomopsis sp. S002, Colletotrichum sp. S028 and Fusarium sp. L031 were higher than 70\% and showed the best inhibitory potential.
\end{abstract}

Keywords Gentiana rhodantha; Endophytic fungi; Diversity; Sclerotinia sclerotionrum; Biocontrol fungi

\section{Introduction}

Endophytic fungi have been isolated in all plant tissues for parts of their life cycle, and not causing obvious symptoms (Wemheuer et al., 2019). Endophytic fungi are abundant in plants, according to conservative estimation, there are more than one million endophytic fungi species distribute in nature (Schmeisser et al., 2007). Endophytes often form a mutualistic interactions with their host, with the relationship benefitting both partners (Deshmukh et al., 2006). The relationships between endophytic fungi and medicinal plants have more reported in recent years. Guo et al. (2000) isolated 25 endophytic strains in Dendrobium officinale, and belonging to 17 genera. Ming et al. (2010) obtained 48 fungal strains in root of ginseng, and they are belonging to 8 family, 9 genera and 12 species by ITS sequences date analysis. Zhang et al. (2019) have shown that group compositions and isolated rate of endophytes were volatile with different collected sites, isolated tissues and seasons.

Endophytic fungi have played a key role in host growth and biotransformation. Partial endophytes can assist host resist pathogen infection and enhancing stress resistance (Peláez et al., 2000; Upson et al., 2009; Chen et al., 2017), regulating seed germination by various means (Biswas and Choudhuri, 1978; Wu and Zhang, 1994; Wang et al., 2013). Few endophytes form coevolution with their host plants and can produce important secondary metabolites with the same or similar active components as their hosts (Wang and Chen, 2011).

Gentiana rhodantha Franch. ex Hemsl, a perennial herb belonging to the Gentianaceae, is mainly distributed at high altitudes $(900 \sim 1800 \mathrm{~m})$ in mountainous areas of southwest China. The aerial parts of this herb (including flower, root, leaf, and stem) are widely used in Tibetan and Miao traditional ethnomedicine for the treatment of cough, bronchitis, hepatitis, jaundice, phthisis, and dysentery (Xu et al., 2011; Shen et al., 2017). G. rhodantha plants have been collected and it is included in the Chinese Pharmacopoeia (2010 edition). Sclerotial stem blight of $G$. rhodantha caused by Sclerotinia sclerotionrum has widely occupied in many fields with higher incidence 
rate by $20 \% \sim 70 \%$, early symptoms are small brown spots in young stem, which expand in node and finally some stem completely wither. In the study, the diversity of endophytic Fungi of G. rhodantha in different areas was analyzed by tissue isolation method. And the strains with significant inhibitory activity against $S$. sclerotiorum were screened from them, which established the foundation for the resource mining of endophytes fungi and the biocontrol of Sclerotial stem blight.

\section{Results and Analysis}

\subsection{Isolation of endophytic fungi}

In the study, 294 fungal strains were obtained in 480 health G. rhodantha tissues fragments by tissue isolation method in 4 collection sites of Liupanshui city, Guizhou, China. Total colonization rate and isolation rate were $49.38 \%$ and $61.25 \%$, respectively, and showed abundant endophytic fungi in G. rhodantha. There are significant differences in four collection sites and three tissues. Colonization rate and isolation rate of Fenghuang, ZS were higher than another three sites, as well as two indexes in root are higher than leaf and stem (Table 1).

Table 1 Colonization rate and isolation rate of endophytic fungi of G. rhodantha in four sites

\begin{tabular}{|c|c|c|c|c|c|c|c|}
\hline $\begin{array}{l}\text { Sampling } \\
\text { sites }\end{array}$ & Organ & $\begin{array}{l}\text { Number of } \\
\text { tissues }\end{array}$ & $\begin{array}{l}\text { Number of tissues } \\
\text { with mycelium }\end{array}$ & $\begin{array}{l}\text { Number of endophytic } \\
\text { fungal strains }\end{array}$ & $\begin{array}{l}\text { Number of } \\
\text { genera }\end{array}$ & $\begin{array}{l}\text { Colonization } \\
\text { rate }(\%)\end{array}$ & $\begin{array}{l}\text { Isolation } \\
\text { rate }(\%)\end{array}$ \\
\hline Collection & Fenghuang, ZS & 120 & 65 & 82 & 28 & 54.17 & 68.33 \\
\hline \multirow[t]{3}{*}{ site } & Nankai, SC & 120 & 62 & 75 & 25 & 51.67 & 62.50 \\
\hline & Yangmei, SC & 120 & 50 & 60 & 23 & 41.67 & 50.00 \\
\hline & Xinchang, LZ & 120 & 60 & 77 & 28 & 50.00 & 64.17 \\
\hline \multirow[t]{3}{*}{ Plant tissue } & Root & 160 & 83 & 102 & 16 & 51.88 & 85.00 \\
\hline & Stem & 160 & 84 & 97 & 17 & 52.50 & 80.83 \\
\hline & Leaf & 160 & 70 & 95 & 14 & 43.75 & 79.17 \\
\hline Total & & 480 & 237 & 294 & 32 & 49.38 & 61.25 \\
\hline
\end{tabular}

\subsection{Endophytic fungal communities}

The 294 strains obtained were identified to genus by morphological and ITS molecular analysis. 156 strains of them were recognized by morphological features and 138 strains were identified based on GenBank BLAST of ITS sequences. The identified resulted showed that the 294 endophytic fungi obtained were belonging to 2 phylum, 5 classes, 14 orders and 32 genera (Table 2); of which Fusarium and Colletotrichum were comparatively advantageous flora in endophytic fungi of $G$. rhodantha, and the species contained occupied $9.86 \%$ and $8.84 \%$ of the total endophytes respectively.

The advantageous taxa have differed significantly in different collected sites and tissue (Figure 1). Fusarium was the dominant genus in four sampling sites, while Alternaria was the dominant fungal flora in Nankai, Shuicheng, but Colletotrichum was a minority. The dominant floras of endophytic fungi were Alternaria and Colletotrichum in leaves, Scopulariops, Periconia and Verticillium in roots and Botryosphaeria, Chaetomium and Fusarium in stems.

\subsection{Fungi diversity of endophytes in different sampling sites and tissues}

Shannon-Weiner index $\left(H^{\prime}\right)$ was used to measure the diversity of endophytic fungi in plants, Pielou evenness index $(J)$ was reflected the distribution uniformity of different species in the community, and Simpson dominance index $(D)$ was used to expressed community compositions. 3 indexes were significantly differences in four sites and three tissues. The $H^{\prime}, J$, and $D$ of endophytic fungi in Xinchang, LZ were higher than another three sites, and the $H^{\prime}, J$ and $D$ of endophytic fungi in stems were higher than leaves and roots (Table 3). The results showed that the distribution of endophytes is uneven in different tissues and growth environments.

\subsection{Similarity degree of endophytic fungi in different sampling sites and tissues}

The Jaccard similarity index $\left(C_{j}\right)$ was used to compare the similarity degree of two fungal taxa. The $C_{j}$ between Fenghuang, ZS and Nankai, SC up to 0.455 and higher than another combination (Table 4). While the $C_{j}$ between any two tissues were below 0.3 , it reveals that there were great differences in endophytic fungi among different tissues (Table 5). 
Molecular Microbiology Research 2021, Vol.11, No.1, 1-9

$\mathrm{http}: / /$ microbescipublisher.com/index.php/mmr

Table 2 Composition and isolation frequency of endophytic fungi in G. rhodantha

\begin{tabular}{|c|c|c|c|c|c|c|c|c|c|c|c|c|c|c|c|c|}
\hline \multirow{2}{*}{$\begin{array}{l}\text { Taxon* } \\
\text { Phylum }\end{array}$} & \multirow[b]{2}{*}{ Class } & \multirow[b]{2}{*}{ Order } & \multirow[b]{2}{*}{ Genus } & \multicolumn{3}{|c|}{ Fenghuang, ZS } & \multicolumn{3}{|c|}{ Nankai, SC } & \multicolumn{3}{|c|}{ Yangmei, SC } & \multicolumn{3}{|c|}{ Xinchang, LZ } & \multirow{2}{*}{$\begin{array}{l}\text { Isolation } \\
\text { frequency }(\%)\end{array}$} \\
\hline & & & & Root & Stem & Leaf & Root & Stem & Leaf & Root & Stem & Leaf & Root & Stem & Leaf & \\
\hline \multirow{16}{*}{ Ascomycota } & Leotiomy- & Helotiales & Botrytis & 1 & - & - & 1 & - & - & - & - & - & 3 & - & - & 1.7 \\
\hline & Cetes & & Marssonina & 3 & 1 & 2 & 1 & 1 & 3 & 1 & 1 & 2 & 1 & 2 & 1 & 6.46 \\
\hline & & & Sclerotinia & - & - & 2 & - & - & 1 & - & - & 1 & - & - & 1 & 1.7 \\
\hline & & & Mycochaetophora & 1 & - & - & 1 & - & - & - & - & - & - & - & - & 0.68 \\
\hline & & & Cylindrosporium & - & - & 2 & - & - & 1 & - & - & 2 & - & - & 3 & 2.72 \\
\hline & & & Cadophora & 2 & - & - & 2 & - & - & 1 & - & - & 2 & - & - & 2.38 \\
\hline & Sordariom-ycetes & Sordariales & Chaetomium & 2 & 3 & - & 2 & 1 & - & 3 & 1 & - & - & 4 & - & 5.44 \\
\hline & & Diaporthales & Phomopsis & - & 3 & 2 & - & 3 & 1 & - & 2 & 2 & - & 1 & 3 & 5.78 \\
\hline & & Hypocreales & Acremonium & - & 1 & - & - & 2 & - & - & 1 & - & - & 3 & - & 2.38 \\
\hline & & & Fusarium & 2 & 3 & 3 & 1 & 1 & 4 & 3 & 2 & 2 & 2 & 3 & 3 & 9.86 \\
\hline & & Glomerellales & Verticillium & 2 & 1 & 1 & 3 & - & 2 & 1 & 2 & 1 & 2 & - & 1 & 5.44 \\
\hline & & & Colletotrichum & 1 & 1 & 7 & 1 & 1 & 8 & - & 1 & - & 1 & 1 & 4 & 8.84 \\
\hline & & & Scopulariopsis & 5 & 1 & 1 & 3 & - & 1 & 3 & 1 & - & 4 & - & 1 & 6.8 \\
\hline & & Amphisphaeriales & Pestalotiopsis & 1 & 2 & - & 1 & 2 & - & 2 & 3 & - & 2 & 1 & - & 4.76 \\
\hline & Eurotiomycetes & Chaetothyriales & Phialophora & - & - & 1 & - & - & 1 & - & - & - & - & - & - & 0.68 \\
\hline & & Eurotiales & Penicillium & - & - & 1 & - & - & - & - & - & 1 & - & - & 1 & 1.02 \\
\hline \multirow[t]{14}{*}{ Ascomycota } & Dothideomycete & Tubeufiales & Letendraea & - & - & 1 & - & - & 3 & - & - & 1 & - & - & 1 & 2.04 \\
\hline & & Monoblastiales & Phoma & - & 2 & - & - & 1 & - & - & 1 & - & - & 2 & - & 2.04 \\
\hline & & Pleosporales & Alternaria & 1 & - & 2 & 2 & 2 & 1 & 2 & 2 & 1 & 2 & 1 & 1 & 5.78 \\
\hline & & & Periconia & 5 & - & - & 4 & - & - & 3 & - & - & 1 & - & - & 4.42 \\
\hline & & & Subplenodomus & - & - & - & - & - & - & - & - & - & - & 1 & - & 0.34 \\
\hline & & & Microsphaeropsis & - & - & 2 & - & - & 1 & - & - & 1 & - & - & 3 & 2.38 \\
\hline & & & Pleospora & - & - & - & - & - & - & - & - & - & 2 & - & - & 0.68 \\
\hline & & & Exserohilum & - & 2 & - & - & 1 & - & - & 1 & - & - & 3 & - & 2.38 \\
\hline & & Capnodiales & Cercospora & - & - & - & - & 2 & - & - & - & - & - & - & - & 0.68 \\
\hline & & & Cladosporium & 2 & - & - & 3 & - & - & 1 & - & - & 2 & - & - & 2.72 \\
\hline & & & Ramularia & - & - & 1 & - & - & - & - & - & 2 & - & - & 1 & 1.36 \\
\hline & & Botryosphaeriales & Fusicoccum & - & 2 & - & - & - & - & - & 2 & - & - & - & - & 1.36 \\
\hline & & & Macrophoma & 1 & - & - & - & - & - & - & - & - & 2 & - & - & 1.02 \\
\hline & & & Botryosphaeria & - & 2 & - & - & 5 & - & - & 4 & - & - & 2 & - & 4.42 \\
\hline \multirow[t]{2}{*}{ Basidiomycot } & Agaricomycetes & Polyporales & Trichaptum & - & 1 & - & - & 1 & - & - & - & - & - & 1 & - & 1.02 \\
\hline & & & Bjerkandera & - & - & - & - & - & - & - & - & - & 2 & - & - & 0.68 \\
\hline Strains number & & & & 14 & 14 & 14 & 13 & 13 & 12 & 10 & 14 & 11 & 14 & 13 & 13 & 100 \\
\hline Genara numbe & & & & 29 & 25 & 28 & 25 & 23 & 27 & 20 & 24 & 16 & 28 & 25 & 24 & 294 \\
\hline
\end{tabular}

Note: Taxonomic status of endophytic fungi based on Dictionary of the Fungi (10th edition) (Kirk et al., 2008) 


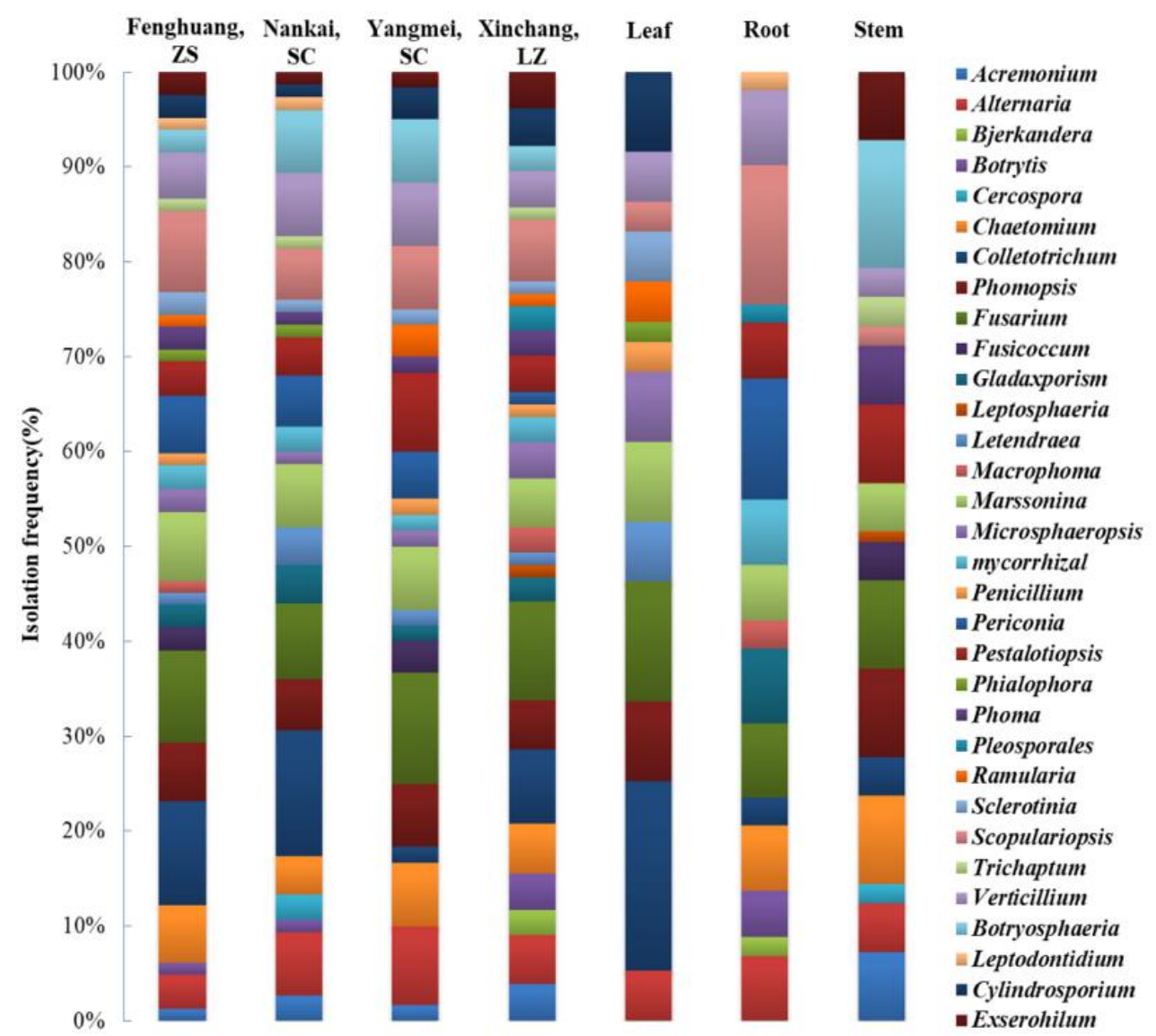

Figure 1 Isolation frequency distribution of endophytic fungi from $G$. rhodantha

Table 3 Diversity indices of endophytic fungi from $G$. rhodantha

\begin{tabular}{|c|c|c|c|c|}
\hline \multicolumn{2}{|c|}{ Sampling information } & \multirow{2}{*}{$\begin{array}{l}\text { Shannon-Weiner index }\left(H^{\prime}\right) \\
3.10\end{array}$} & \multirow{2}{*}{$\begin{array}{l}\text { Pielou evenness index }(J) \\
0.70\end{array}$} & \multirow{2}{*}{$\begin{array}{l}\text { Simpson dominance index }(D) \\
0.94\end{array}$} \\
\hline Collection & Fenghuang, ZS & & & \\
\hline sites & Nankai, SC & 3.02 & 0.70 & 0.94 \\
\hline & Yangmei, SC & 2.96 & 0.72 & 0.94 \\
\hline & Xinchang, LZ & 3.17 & 0.73 & 0.95 \\
\hline \multirow[t]{3}{*}{ Plant tissue } & Root & 2.61 & 0.57 & 0.92 \\
\hline & Stem & 2.74 & 0.60 & 0.93 \\
\hline & Leaf & 2.47 & 0.54 & 0.90 \\
\hline
\end{tabular}

Table 4 Similarity coefficients of endophytic fungi from G. rhodantha in different sites and tissues

\begin{tabular}{lllll}
\hline Sampling sites & Fenghuang,ZS & Nankai, SC & Yangmei, SC & Xinchang, LZ \\
\hline Fenghuang, ZS & 1.000 & - & - & - \\
Nankai, SC & 0.455 & 1.000 & - & - \\
Yangmei, SC & 0.453 & 0.420 & 1.000 & - \\
Xinchang, LZ & 0.439 & 0.407 & 0.423 & 1.000 \\
\hline
\end{tabular}

Table 5 Similarity coefficients of endophytic fungi from G. rhodantha in different tissues (Cj)

\begin{tabular}{llll}
\hline Isolated tissues & Root & Stem & Leaf \\
\hline Root & 1.000 & - & - \\
Stem & 0.252 & 1.000 & - \\
Leaf & 0.200 & 0.215 & 1.000 \\
\hline
\end{tabular}




\subsection{Screening for biocontrol stains}

The 24 strains of endophytic fungi with inhibition rates above $50 \%$ were screened out in study confronted with $S$. sclerotionrum (Table 6). Among them, the inhibition rate of Botryosphaeria sp. R022 was up to $86 \%$ and significantly higher than another 23 strains, Phomopsis sp. S002, Botryosphaeria sp. R021 and Colletotrichum sp. S028 were above $70 \%$. Among the strains that inhibition rate higher than 50\%, strains of Fusarium and Chaetomium were largest proportion and reached $13.04 \%$, the two genera fungi may play an important role in resistant process of $G$. rhodantha (Figure 2).

Table 6 Inhibitory effects of endophytic fungi of G. rhodantha on S. sclerotionrum

\begin{tabular}{|c|c|c|c|c|}
\hline$\underline{\text { Strain number }}$ & Isolation tissue & Genus & Strain confrontation radius $(\mathrm{mm})$ & Inhibition rate $(\%)$ \\
\hline R022 & Root & Botryosphaeria & 6.3 & $86.00 \pm 4.21 \mathrm{a}$ \\
\hline S002 & Stem & Phomopsis & 11.2 & $75.11 \pm 3.33 \mathrm{~b}$ \\
\hline R021 & Root & Botryosphaeria & 12.0 & $73.33 \pm 2.54 \mathrm{~b}$ \\
\hline S028 & Stem & Colletotrichum & 12.0 & $73.33 \pm 4.21 \mathrm{~b}$ \\
\hline L031 & Leaf & Fusarium & 12.7 & $71.78 \pm 2.34 \mathrm{bc}$ \\
\hline L903 & Leaf & Chaetomium & 13.6 & $69.78 \pm 5.21 \mathrm{c}$ \\
\hline R011 & Root & Botrytis & 13.6 & $69.78 \pm 3.21 \mathrm{c}$ \\
\hline S008 & Stem & Chaetomium & 13.6 & $69.78 \pm 2.35 \mathrm{c}$ \\
\hline S014 & Stem & Leptosphaeria & 14.3 & $68.22 \pm 2.35 \mathrm{c}$ \\
\hline L004 & Leaf & Fusarium & 15.0 & $66.67 \pm 1.58 \mathrm{c}$ \\
\hline S023 & Stem & Cladosporium & 15.0 & $66.67 \pm 1.58 \mathrm{c}$ \\
\hline S017 & Stem & Cercospora & 15.0 & $66.67 \pm 3.25 \mathrm{c}$ \\
\hline R017-1 & Root & Periconia & 15.1 & $66.44 \pm 3.55 \mathrm{c}$ \\
\hline S001 & Stem & Scopulariopsis & 15.5 & $65.56 \pm 5.22 \mathrm{c}$ \\
\hline S012 & Stem & Verticillium & 16.0 & $64.44 \pm 5.42 \mathrm{c}$ \\
\hline R034 & Root & Pleosporales & 16.2 & $64.00 \pm 3.52 \mathrm{~cd}$ \\
\hline R031-2 & Root & Fusarium & 16.5 & $63.33 \pm 5.24 \mathrm{~cd}$ \\
\hline S022 & Stem & Alternaria & 17.0 & $62.22 \pm 6.25 \mathrm{~cd}$ \\
\hline S013 & Stem & Phoma & 17.1 & $62.00 \pm 5.24 \mathrm{~d}$ \\
\hline R020 & Root & Mycochaetophora & 17.5 & $61.11 \pm 3.25 \mathrm{~d}$ \\
\hline L022 & Leaf & Letendraea & 18.0 & $60.00 \pm 5.32 \mathrm{e}$ \\
\hline R017-2 & Root & Periconia & 18.0 & $60.00 \pm 6.20 \mathrm{e}$ \\
\hline L101 & Leaf & Chaetomium & 18.1 & $59.78 \pm 4.23 \mathrm{e}$ \\
\hline R000 & Root & Acremonium & 19.0 & $57.78 \pm 3.25 \mathrm{f}$ \\
\hline Indicator & S. sclerotionrum & & 45 & 0.00 \\
\hline
\end{tabular}

Note: Different lowercase letters in the same column of data indicate significant differences at the level of $0.05(\alpha=0.05)$
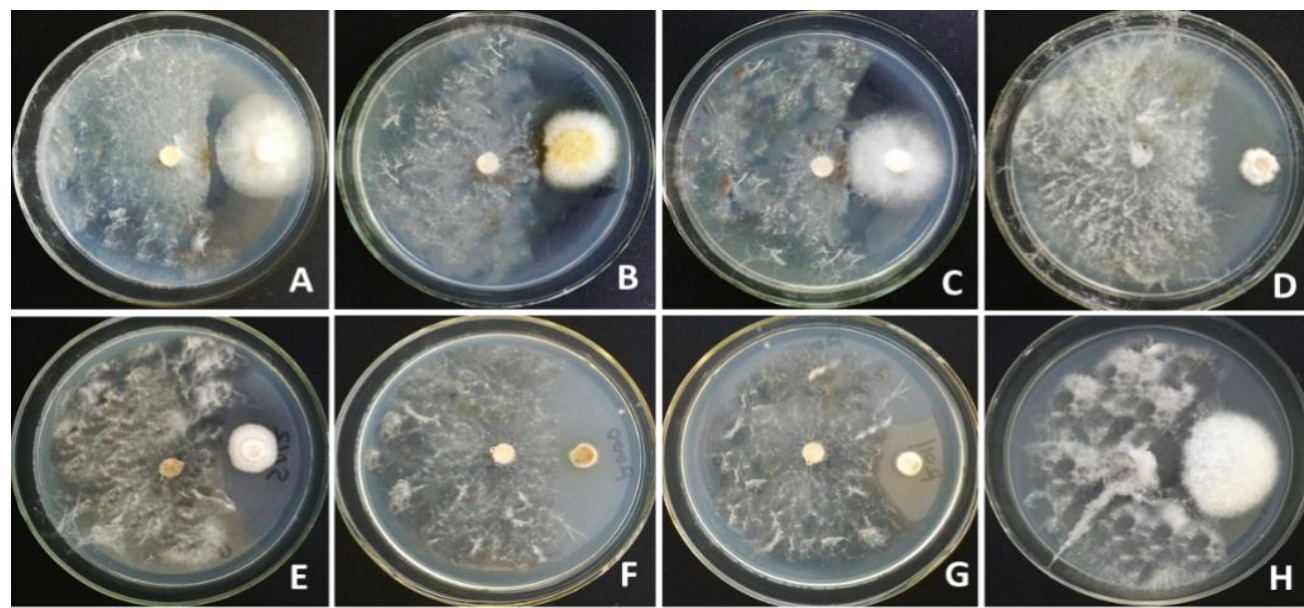

Figure 2 Effect of mycelium of $S$. sclerotionrum confront with partly endophytic fungi of $G$. rhodantha. Note: A: R021, B: R903, C: R022, D: R031-2, E: S012, F: R000, G: R011, H: S023 


\section{Discussion}

In study, the 294 endophytic strains obtained were belonging to 2 phylum, 5 classes, 14 orders and 32 genera; of which Fusarium and Colletotrichum were comparatively advantageous taxa, but their advantages were not obvious with isolation frequencies less than $10 \%$. Total colonization rate of whole strains was from $41 \%$ to $54 \%$. Compared with the roots and stems, the number of endophytic fungal strains, genera and diversity indexes in leaves were significantly decreased, which were different with previous reports that the diversity of fungi in leaves was higher than that in stems (Qiao et al., 2018; Lu et al., 2020; Zang et al., 2020), It may be due to the inherent distribution characteristics of endophytes in the leaves of $G$. rhodantha, or some sensitive fungi with poor resistance in thin leaves were inactivated in long disinfection time.

Some low frequency genera (isolation frequency $\leq 1.0 \%$ ) obtained are closely related to Gentiana plants growth. Such as Subplenodomus (0.34\%), Bjerkandera (0.68\%) Cercospora (0.68\%) Mycochaetophora (0.68\%), Phialophora (0.68\%) and Pleosporales $(0.68 \%)$, Among them, brown leaf spot on G. Triflora caused by M. Gentianae (Nekoduka et al., 2013), and brown root rot of prairie gentian caused by S. Drobnjacensis (Kondo et al., 2014). The rare genus strains that low frequency may be growth in unsuitable PDA medium and covered by rapidly growing mycelium (Ma et al., 2014).

The population structures of endophytes floras in same host are variable due to different growth surroundings and seasons (Qiao et al., 2018), In the study, the Shannon-Weiner diversity index $\left(H^{\prime}\right)$, Pielou evenness index $(J)$ and Simpson dominance index $(D)$ of endophytic fungi in Xinchang, LZ were higher than another three sites, and The $H^{\prime}, J$ and $D$ of endophytic fungi in stems were higher than leaves and root, it may be that the environmental conditions of Xinchang site are more suitable for the colonization of endophytes, which were also formed a mechanism of mutual adaptation between plants and endophytes in the long-term evolution process (Zang et al., 2020).

According to conservative estimate, about $90 \%$ of the one million endophytic fungi in nature are not culturable. In recent years, we are greatly expanded the understanding of plant endophytes by metagenomic DNA sequencing and analysis technology. Zhao et al. (2017) discovered that the advantage taxa of endophytic fungi were non-culture in vitro. Yang et al. (2018) was identified 150 genera of endophytic fungi carried out the genomic analysis and very significantly more than 20 genera by tissue-separation. So, it is not comprehensive to study the diversity of endophytes by tissue-isolation method.

Endophytic fungi have played a key role in host growth and biotransformation. For example, endophytic can synthetic and secret some antibacterial substances to resist the pest and enhance growth and tissue repairing of host (Peláez et al., 2000; Upson et al., 2009), scramble for nutrition and growth space with pathogens (Liao et al., 2018) and stimulate host to produce non-specific immunity (Chen et al., 2017). In the study, some strains with significant inhibitory activity against $S$. sclerotiorum were screened, which established the foundation for the resource mining of endophytes fungi and the biocontrol of Sclerotial stem blight.

\section{Materials and Methods}

\subsection{Sampling collection and endophytic fungi isolation}

The fresh, healthy tissues of G. rhodantha were collected from Fenghuang of Zhongshan District, Nankai and Yangmei of Shuicheng county, and Xinchang of Liuzhi Special District, Liupanshui City, Guizhou provinces, China (Table 7) in August to September, 2019. Three samples from each tissue (root, leaf and stem) from different sites and stored in ice box, were sent to laboratory and stored in the refrigerator at $4^{\circ} \mathrm{C}$. All the samples obtained were isolated in two days.

The diseased samples of $G$. Rhodantha sclerotial stem blight were collected Fenghuang, Zhongshan District, and strain Sclerotinia sclerotionrum SB062901 was obtained by tissue-isolation method from typical lessons, and caused same stem necrosis symptoms in pathogenicity test, and identified by mycelium features and ITS sequence analysis. Its ITS-rDNA was submitted to GenBank (Accession numbers: MT620768). 
Table 7 Sampling locations of Gentiana rhodantha

\begin{tabular}{llllllll}
\hline \multicolumn{2}{l}{ Sampling sites } & Shorthand & Elavation $(\mathrm{m})$ & Longitude & Latitude & Annual & average Annual sunshine \\
\hline Zhongshan & Fenghuang & Fenghuang,ZS & 1920 & $104^{\circ} 49^{\prime} 48^{\prime \prime} \mathrm{E}$ & $26^{\circ} 34^{\prime} 48^{\prime \prime} \mathrm{N}$ & 12.3 & 1253 \\
Shuicheng & Nankai & Nankai, SC & 1630 & $105^{\circ} 0^{\prime} 36^{\prime \prime} \mathrm{E}$ & $26^{\circ} 46^{\prime} 12^{\prime \prime} \mathrm{N}$ & 12.2 & 1760 \\
& Yangmei & Yangmei, SC & 735 & $104^{\circ} 50^{\prime} 58^{\prime \prime} \mathrm{E}$ & $26^{\circ} 21^{\prime} 81^{\prime \prime} \mathrm{N}$ & 12 & 1700 \\
\multirow{2}{*}{ Liuzhi } & Xinchang & Xinchang, LZ & 1620 & $105^{\circ} 18^{\prime} 8^{\prime \prime} \mathrm{E}$ & $26^{\circ} 24^{\prime} 49^{\prime \prime} \mathrm{N}$ & 13.3 & 1850 \\
\hline
\end{tabular}

Initially the excised materials were cleaned under running tap water and the healthy samples were washed with sterile water 3 5 times and blow dried the water on super-clean worktable. They were surface-sterilized successively with $75 \%$ ethanol for $1 \mathrm{~min}$, and then soaked in $5 \%$ sodium hypochlorite $(\mathrm{W} / \mathrm{V})$ for $3 \mathrm{~min}$, then rinsed with sterile water five times and cut into about $5 \times 5 \mathrm{~mm}$ pieces with sterile scissors and then dried on sterile filter papers and then placed on $9 \mathrm{~cm} \mathrm{50 \%} \mathrm{PDA} \mathrm{plates} \mathrm{that} \mathrm{medium} \mathrm{added} \mathrm{streptomycin} \mathrm{sulfate}(50 \mathrm{U} / \mathrm{mL})$ and penicillin sodium $(30 \mathrm{U} / \mathrm{mL})$ and incubated at $25^{\circ} \mathrm{C}$. Each sample sites were inoculated with 40 pieces of root, stem and leaf tissues. After $5 \sim 10$ days, cat rice grains-like agar pieces placed on PDA plates, then obtained pure cultures after repeated the above process one or two times. All the strains were preserved on PDA slants and stored at $4^{\circ} \mathrm{C}$ at the Microbiology Laboratory of Liupanshui Normal University.

\subsection{Identification of endophytic fungi of $G$. rhodantha}

The endophytic fungi were identified to genus grades by morphological characteristics and molecular analysis. All endophytic strains were cultured on the MEA and PDA medium at $25^{\circ} \mathrm{C}$ for 40 days in alternate $12 \mathrm{~h}$ light and dark. Morphological characteristics of strains including colony features, hypha, sporophore and spore were observed and described according to flora Fungorum Sinicorum Series, Fungal Identification Manual (Wei, 1979) and Illustrated Genera of Imperfect Fungi (Barnett et al., 1955).

Total genomic DNA of fresh pure cultures was extracted using the amended Cetyltrimethyl Ammonium Bromide (CTAB) method (Zhang et al., 2008). The ITS region of rDNA molecule was amplified using primer pairs ITS1and ITS4. PCR was performed with the $25 \mu \mathrm{L}$ reaction system consisting of $19.75 \mu \mathrm{L}$ of double distilled water, $2.5 \mu \mathrm{L}$ of $10 \times$ Taq buffer with $\mathrm{MgCl} 2,0.5 \mu \mathrm{L}$ of $\mathrm{dNTP}(10 \mathrm{mM}$ each $), 0.5 \mu \mathrm{L}$ of each primer $(10 \mu \mathrm{M}), 0.25$ $\mu \mathrm{L}$ Taq DNA polymerase $(5 \mathrm{U} / \mu \mathrm{L})$, and $1.0 \mu \mathrm{L}$ of DNA template. PCR amplification protocols were performed as described by Liu et al. (2017). All ITS-rDNA sequences in this study were submitted to GenBank (Accession numbers were from MT576347 to MT576484). The sequences were used as query sequences to search for ally sequences from GenBank using the Blast tool. The ally sequences were then obtained and used for subsequent phylogenetic analyses.

\subsection{Screening of biocontrol strains}

A mycelial discs (6 mm diam) of $S$. sclerotionrum SB062904 was placed at the center of $9 \mathrm{~cm}$ PDA plates, and then inoculated an endophytic fungal discs and $2 \mathrm{~cm}$ away from the plate center. Measured the adversarial radius of strain SB062904 when opposite mycelium was extended at dish edge. Calculation of inhibition rates of endophytic fungi were referred to Liu et al. (2015).

\subsection{Assessment of data}

The isolation frequency $(I F)$ of fungi was calculated as the number of isolates of one taxon divided by the total number of isolates, and expressed as a percentage, the colonization rates $(C R)$ was calculated as number of tissues with mycelium divided by the total number of tissue (Chai et al., 2016; Zhang et al., 2019).

Shannon-Wiener index $\left(H^{\prime}\right)$ and Simpson index $(D)$ were used for the biodiversity of the endophytic fungi. The formula: $H^{\prime}=\sum_{i=1}^{n}[-P i \cdot \ln (P i)], D=1-\sum_{i=1}^{n}(P i)^{2}$, where the ratio $P i$ is the frequency of colonization of the taxon in the sample (Sun and Liu, 2004; Schmeisser et al., 2007). Pielou evenness index $(J)$ was used for the uniformity of the endophytic fungi. The formula: $J=\sum_{i=1}^{n}\left[\frac{-P i \cdot \ln (P i)}{\ln S}\right]$, where the $S$ is the number of total fungal isolated. 
The Jaccard similarity index $\left(C_{j}\right)$ was a important quota to compared the similarity of endophytes between each two plant materials. $C_{j}=\frac{|A \cap B|}{|A \cup B|}$ (Yang and Wei, 2018).

\section{Authors' contributions}

Xiaoyong Zhang and Shujiang Li were performed the experiments, analyzed the data, contributed reagents materials/analysis tools, prepared figures and/or tables, authored or reviewed drafts of the paper, approved the final draft.Youlian Yang was conceived and designed the experiments, analyzed the data and reviewed manuscript and approved the final draft.Kai Yan was contributed reagents materials and approved the final draft.

\section{Acknowledgments}

The research was funded by Youth Science and Technology Talent Cultivating Project of Guizhou Department of Education (QJH KY[2018]381), Construction Project of Key and Distinctive Laboratory of Guizhou General University (QJH KY2017[012]) and Natural Science Foundation of Guizhou Province (QKH J[2014]7447).

\section{References}

Barnett H.L., Hunte B.B., eds., and Shen C.Y., trans., 1977, Illustrated genera of imperfect fungi, Science Press, Beijing, China, pp: 1-240

Biswas A.K., and Choudhuri M.A., 1978, Deferral of leaf senescence and increased productivity in rice, Nuclear Agriculture, (7): 14-18

Chai X.Y., Chai G.Q., and Xiang Y.Y, 2016, Composition and ecological distribution of endophytic and epiphytic fungi from the foliage of Pteroceltis tatarinowii, Shengtai Xuebao (Acta Ecologica Sinica), 36(16): 5163-5172 https://doi.org/10.5846/stxb201501290233

Chen D.J., An M.M., and Li L.L., 2017, The mechanism of phytoalexin enhancing crop disease resistance, Fenzi Zhiwu Yuzhong (Molecular Plant Breeding), 15(2): 774-780

Deshmukh S., Huckelhoven R., Schafer P., Imani J., Sharma M., Weiss M., Waller F., and Kogel K.H., 2006, The root endophytic fungus Piriformospora indica requires host cell death for proliferation during mutualistic symbiosis with barley. Proc. Natl. Acad. Sci. USA., 103(49):18450-18457 https://doi.org/10.1073/pnas.0605697103 PMid:17116870 PMCid:PMC1697795

Guo S.X., Cao W.C., and Gao W.W., 2000, Isolation and biological activity of mycorrhizal fungi from Dendrobium candidum and D.nobile, Zhongguo Zhongyao Zazhi (China Journal of Chinese Materia Medica), 25(6): 18-21

Kirk P.M., Cannon P.F., and Stalpers J.A., 2008, Dictionary of the Fungi (10th Edition), Cambridge University Press, Cambridgeshire, United Kingdom, pp. $1-771$

Kondo T., Satou M., and Morikawa T., 2014, Brown root rot of Russell prairie gentian caused by Subplenodomus drobnjacensis. J. Gen. Plant Pathol., 80(1): 99-102 https://doi.org/10.1007/s10327-013-0480-4

Liao Q.H, Li Y.B., Liu Q., Yang S.C., and Liu T., 2018, Isolation and identification of endophytic bacteria in Paris polyphylla var. yunnanensis, Fenzi Zhiwu Yuzhong (Molecular Plant Breeding), 16(18): 6156-6160

Liu C.Y., Xu R.R., Li H.L., and Chang Z.L., 2015, Isolation, screening and identification of an endophytic fungus and the detection of its antifungal effects, Zhiwu Baohu Xuebao (Journal of Plant Protection), 42(5): 806-812

Liu F., Hou L.W., Raza M., and Cai L., 2017, Pestalotiopsis and allied genera from camellia, with description of 11 new species from China, Scientific Reports, 7(1): $1-18$ https://doi.org/10.1038/s41598-017-00972-5 PMid:28408743 PMCid:PMC5429834

Lu D.S., Wu H., Shi L.S., and Chen J.F., 2020, Studies on diversity of endophytic fungi in Bidens frondosa, Xinyang Shifan Xueyuan Xuebao (Journal of Xinyang Normal University), 33(1): 42-45, 96

Ma Y., Wang L.H., Li Y.M., Sun C., and Li B., 2014, Community diversity of endophytic fungi of Aloe barbadensis, Weishengwuxue Tongbao (Microbiology China), 41(11): 2235-2243

Ming Q.L., Xu L.L., Han T., and Qing L.P., 2010, Study on the diversity of the panax ginseng endophytic fungi, Renshen Yanjiu (Genseng Research), 22(2): 2-8

Nekoduka S., Tanaka K., and Sano T.S., 2013, Overwintering of brown leaf spot fungus, mycochaetophora gentianae, in infected gentian leaves as the primary inoculum source, J. Gen. Plant Pathol., 79: 175-177 https://doi.org/10.1007/s10327-013-0438-6

Peláez F., Cabello A., and Platas G., 2000, The discovery of enfumafungin, a novel antifungal compound produced by an endophytic Hormonema species biological activity and taxonomy of the producing organisms, Syst. Appl. Microbiol., 23(3): 333-343 https://doi.org/10.1016/S0723-2020(00)80062-4

Qiao L.J., Zhou S.X., Wen T.C., Kang J.C., and Lei B.X., 2018, Diversity of endophytic fungi from Nothapodytes pittosporoides in Guizhou Province, Junwu Xuebao (Mycosystema), 37(1): 43-51

Schmeisser C., Steele H., and Streit W.R., 2007, Metagenomics, biotechnology with non-culturable microbes, Appl. Microbiol. Biotechnol., 75(5): 955-962 https://doi.org/10.1007/s00253-007-0945-5

PMid: 17396253 
Shen T., Zhang J., Shen S.K., Zhao Y.J., Wang Y.Z., 2017, Distribution simulation of Gentiana rhodantha in Southwest China and assessment of climate change impact, Chinese Journal of Applied Ecology 28(8): 2499-2508

Sun H.X., and Liu X.L., 2004, Microbes studies of tea rhizosphere, Shengtai Xuebao (Acta Ecologica Sinica), 24(7): 1353-1357

Upson R., Read D.J., and Newsham K.K., 2009, Nitrogen form influences the response of Deschampsia antarctica to dark septate root endophytes, Mycorrhiza, 20: $1-11$ https://doi.org/10.1007/s00572-009-0260-3 PMid:19495811

Wang M.Q., Lu H.B., Zhao L.J., and Hao X.J., 2013, Growth-promoting action on tomato and cucumber by walnut endophytic HT3, Shangxi Nongye Kexue (Journal of Shanxi Agricultural Sciences), 41(2): 130-132, 139

Wang Y.M., and Chen H.Z., 2011, Isolation and identification of a camptothecin-producing endophytic fungus from Camptotheca acuminate, Weishengwuxue Tongbao (Microbiology China), 38(6): 884-888

Wei J.C., 1979, Fungal identification manual, Shanghai: Shanghai Science and Technical Publishers, Shanghai, Chian, pp.1-780

Wemheuer F., Wemheuer B., Daniel R., and Vidal S., 2019, Deciphering bacterial and fungal endophyte communities in leaves of two maple trees with green islands, Sci. Rep.s, 9(1): 14183 https://doi.org/10.1038/s41598-019-50540-2 PMid:31578453 PMCid:PMC6775154

Wu J.P., and Zheng S.Z., 1994, Isolation and identification of fusarium sp. from mycorrhiza fungus in Dendrobium densiflorum and analyses of its metabolites, Fudan Xuebao (Journal of Fudan University), 33(5): 547-553

Xu M, Zhang M, Wang D., Yang C.R., and Zhang Y.J., 2011, Phenolic compounds from the whole plants of Gentiana rhodantha (gentianaceae), Chemistry and Biodiversity, 8(10), 1891-1900 https://doi.org/10.1002/cbdv.201000220 PMid:22006717

Yang H.J., Ye W.W., Ma J.X., Zeng D.D., Rong Z.Y., Xu M., Wang Y.C., and Zheng X.B., 2018, Endophytic fungal communities associated with field-grown soybean roots and seeds in the Huang-Huai region of China, PeerJ., 6: e4713

https://doi.org/10.7717/peerj.4713 PMid:29736345 PMCid:PMC5933319

Yang Y., and Wei J., 2018, High-throughput sequencing analysis of the fungal diversity in the soil under the fairy ring fruitbodies of Leucocalocybe mongolicum, Fenzi Zhiwu Yuzhong (Molecular Plant Breeding), 16(10): 3412-3422

Zang W., Luke S.N.K., Shen C., Du Z.N., Sun X., Sun J.Q., and Fu J.W., 2020, Species diversity and community composition of endophytic fungi fromrelict tree fern Alsophila spinulosa, Junwu Xuebao (Mycosystema), 39(4): 731-742

Zhang H.F., Huang Y., Li S.Q., Ouyang J.P., He G., and Chen Y., 2019, Diversity of endophytic fungi isolated from Selaginella tamariscina, Junwu Xuebao (Mycosystema), 38(11): 1886-1893

Zhang Y.H., Wei D.S., Xing L.J, and Li M.C., 2008, A modified method for isolating DNA from fungus, Weishengwuxue Tongbao (Microbiology China), 35(3) : 466-469

Zhao Q., Deng Y.Y., Li W., Sun H.Y., Xia Y.L., and Chen H.G., 2017, Analysis of endophytes diversity in wheat seedlings by metagenomic technology, Zhiwu Bingli Xuebao (Acta Phytopathologica Sinica), 47(3): 313-324 